\title{
Frygten for en religiøs tsunami
}

\section{Anders Jerichow}

\section{Både Vesten og konservative arabiske regeringer frygter efter opløsningen i Irak, Libanon og Gaza en fundamentalistisk bølge over Mellemøsten. I modsætning til Iran søger Vesten ikke indflydelse i de politisk-religiøse netværk}

Det ville være så enkelt, om end ikke nødvendigvis mindre blodigt, hvis 'Mellemøstkonflikten' kun handlede om arabere mod israelere.

I dag konkurrerer tre konflikter i Mellemøsten - i Gaza, Irak og Libanon - om både lokal, regional og international opmærksomhed. De har alle potentiale til at sætte mere end blot de tre samfund selv i brand. $\mathrm{Og}$ både arabiske regeringer og 'det internationale samfund' - læs hér: Vesten - frygter, at Irans skjulte hænder er bag de tre konflikter, og at en iransk inspireret bølge af fundamentalisme er på vej ind over Arabiens kyster. Det ville utvivlsomt glæde Iran. Men virkeligheden er formentlig mere kompliceret.

For få år siden ville arabiske nationalister have troet og hævdet, at net- op den arabisk-israelske konflikt var nøglen til alt andet. I dag er det svært at hævde, at en løsning på den ene konflikt automatisk vil føre til løsninger på de andre. Selv hvis israelere og palæstinensere mirakuløst enedes om en kontant afslutning af deres historiske mellemværende, ville opløsningen af Irak stadig være faretruende, og Libanons centrifugale kræfter ville stadig true denne stat på eksistensen.

Nej, i dette forår 2007 har de fleste arabiske og vestlige regeringer været mere optaget af en helt anden tendens i Mellemøsten. Både i selve regionen og $\mathrm{i}$ 'det internationale samfund' oplevede regeringer et deja-vu fra det iranske revolutionsår 1979, hvor Ayatollah Khomeini spredte angst i hele regionen. En 
snigende fornemmelse har i 2007 bredt sig af en omsiggribende religiøs fundamentalisme, som støt har domineret dagsordenen i såvel Irak som Libanon og Gaza, anført af revolutionære grønne faner og med et rødt spor af blod bag sig.

Og her er konservative arabiske regeringer og Israel ikke uenige. Tvært imod: De er lige urolige ved den religiøse fundamentalisme. $\mathrm{Og}$ de var enige om at se en skjult iransk hånd bag opløsningen i Irak, bag Hizbollah-bevægelsens voksende indflydelse i det centrale Libanon, om end næppe bag Fatah alIslams oprør i det nordlige Libanon, og bag Hamas-bevægelsens magtovertagelse i Gaza-striben.

De er også enige om at se Syrien som det eneste arabiske land med konkret evne til at skrue op og ned for volden i både Irak, Libanon og Gaza.

\section{Nationalisme først}

Irans præstestyre ville formentlig elske at have så stor en indflydelse, som konservative arabiske og vestlige regeringer tiltror det. Alligevel kan Iran ikke tillægges et ansvar for, at de konflikter i Gaza, Libanon og Irak i første omgang brød ud, højest for at pirke til konflikterne, da de var en kendsgerning.

Iran har jo også sine strategiske interesser. For præstestyret var det lidt af et mareridt, at USA inden for ét år intervenerede i dets to vigtigste nabolande, Afghanistan og Irak. Ganske vist udgjorde Saddam Husseins regime i Irak en ærkefjende for præstestyret i Teheran; trods alt havde Saddam Hussein påført Iran otte års krig 1980-88 og enorme ødelæggelser. Og Iran havde også været belastet af Afghanistans konflikter, som under den sovjetiske besættelse havde sendt halvanden million flygtninge ind i Iran i1980'erne.

Men derfra og til at få amerikanerne ind next door, i 2001 og 2003, efter at USA havde opfordret til regime-skift i Teheran, var ikke en ønskværdig udvikling for den iranske revolution.

Til gengæld var det ikke kun USA, som kunne trække på råd fra 'gode venner' i de to lande (den 'nordlige alliance' i Afghanistan og eksil-irakere som Ahmad Chalabi i Irak). Præstestyret i Iran havde også sine alliancer at trække på. I det vestlige Afghanistan havde Iran tætte kontakter til krigsherrer og guvernøren i Heraz. I det sydlige Irak havde Iran tætte kontakter til politisk-religiøse ledere, som havde tilbragt adskillige år i iransk eksil, mens Saddam Hussein undertrykte sit land.

Den opsigtsvækkende historiske lektie er knap nok, at både USA og Iran således begge - og med forskelligt udbytte - kunne trække på lokale allierede, hvor det måtte sandes, at Irans venner havde bedre rødder i lokalmiljøet end USA's.

Nej, lektien har for såvel USA som Iran været, at nationalismen i både 
Afghanistan og Irak har vist sig stærkere end religiøse eller politiske bånd på tværs af grænser.

I Afghanistan samarbejdede den nordlige alliance gerne med USA om at fortrænge Taleban-bevægelsen fra magten i 2001, men efterfølgende har USA's og NATOs voksende konflikt med Talebans omgrupperede styrker vist en tiltagende afghansk modvilje mod at blive underlagt fremmede styrker. Iran har heller aldrig været i stand til at skaffe sig en dominerende indflydelse i det vestlige Afghanistan.

Samme lektie har gentaget sig i Irak, hvor især shia-muslimske arabere og kurdere var godt tilfredse med USA's held til at drive Saddam Hussein fra magten i foråret 2003. I dag, fire år senere, er det stadig akademisk interessant, hvad der gik galt. Men i praksis er der ikke tvivl om, at irakerne i takt med opløsningen af landets politiske og administrative struktur også har vendt sig mod de især amerikanske styrker, som påtog sig et ansvar for landets genopbygning og interne sikkerhed, men knap kunne levere nogle af delene. Skønt det iranske præstestyre ikke brød sig om at se amerikanske soldater på mellemøstlig jord, iagttog præstestyret fjernelsen af Saddam Husseins diktatur og senere hans henrettelse med en uomtvistelig tilfredshed.

Men længere var den iranske tilfredshed heller ikke. Præstestyret var parat til at spille sine egne kort.
Ligesom det udviklede sine bånd til lokale magthavere i det vestlige Afghanistan i 2001, tilbød det hurtigt i 2003 politisk og teknisk-militær hjælp til shiitiske partier og militser i Irak. Også Iran skulle dog lære, at hverken afghanere eller de irakiske bevægelser vægter de religiøse bånd, som de har til fælles med Irans befolkningsflertal, højere end deres respektive nationale identitet.

I Irak satser ingen shiitisk bevægelse på løsrivelse fra Bagdad til fordel for en efterfølgende tilknytning til Iran. Den nationale identitet er stærkere end den religiøse.

I bund og grund har præstestyret i Teheran selv vist sig mere nationalistisk end optaget af at eksportere sin religiøse revolution. Præstestyret har, islamisk revolution eller ej, afholdt sig fra at blande sig i aktivt i krigen om Kuwait (1990/91), i den efterfølgende konflikt i Sydirak 2001, i konflikten i nabolandet Aserbajdsjan først i 1990'erne ligesom i de nævnte konflikter i Irak, Libanon og Gaza. Våbenhjælp og økonomisk assistance er aldrig strakt så langt, at Iran har ønsket at risikere krig ved præstestyrets egne grænser.

\section{Hizbollahs Libanon}

I Libanon, hvor den shiamuslimske Hizbollah-bevægelse har skaffet sig voksende indflydelse, har det været fristende for både arabiske og udenlandske observatører at fokusere på Hizbollahs iranske forbindelse. 
På husfacader i Beiruts shiitiske kvarterer kan man stadig rende ind $\mathrm{i}$ store billeder af Irans shiitiske ledere. Men tag ikke fejl. Hizbollah har fået sin folkelige popularitet som socialt netværk og ikke mindst som national modstandsbevægelse under Israels besættelse af Sydlibanon 1982-1990. I sin politiske retorik og i sin selvfølelse er Hizbollah stadig en modstandsbevægelse, selvom den i praktisk libanesisk politik nu fokuserer på at skaffe sig regeringsindflydelse, på at få ændret den libanesiske forfatning, som giver det kristne mindretal en slags vetoret, og på at fastholde bevægelsens ret til - i modsætning til andre militser - at bære våben.

Ingen tvivl om, at især det kristne Libanon, men også især konservative sunnimuslimske kredse, i sommeren 2006 var skræmt og forarget over, at Hizbollah var i stand - og parat - til at udløse en krig med Israel i Sydlibanon. Men langt større var beundringen hos Libanons egne shiamuslimer - og i arabisk-nationalistiske kredse ude i den øvrige arabiske verden - over, at Hizbollah kunne holde Israels militære styrker hen i en måned. Det vendte i arabisk bevidsthed det konkrete militære nederlag til en politisk-psykologisk sejr.

Hizbollah har sine våben og en massiv politisk støtte fra såvel Iran som Syrien. De tætte politiske og $\varnothing$ konomiske forbindelser giver formentlig også Iran og Syrien en bety- delig opmærksomhed hos Hizbollahs leder, Hassan Nasrallah. Men er der grund til at mene, at Hizbollah har deponeret sin politiske beslutningskraft hos Iran? Nej. Er der nogen dokumentation for, at Hizbollah konkret vil tjene som fjernstyret våben for præstestyret i Iran? Slet ikke. Hizbollah er national-religiøst og i bund og grund forankret i libanesisk politik.

\section{Hamas' pragmatisme}

Så Gaza da! Er det her, vi finder beviset på Irans skjulte hånd? Hamasledere har indrømmet at have modtaget rede kontanter fra Iran (begge parter foretrækker amerikanske dollar). Og sandt at sige befinder Hamas' politiske overhoved, Khaled Meshal, sig jo i Syriens hovedstad, Damaskus, hvorfra iranske gesandter også kommunikerer med Hizbollah i Libanon, eller hvad?

Det er uomtvisteligt, at Hamas ligesom Hizbollah har gode politiske forbindelser til Iran. De to bevægelser, som også har til fælles, at de driver store sociale netværk, som på mange måder matcher det 'statslige' velfærdssystem, har desuden til fælles, at iranske forsøg på at smugle våben ind til dem er blevet afsløret og derfor dokumenteret.

Men Hamas har tidligere modtaget penge fra saudiarabiske kilder. Bevægelsen har også fået støtte fra Egyptens muslimske broderskab, som den selv udspringer af. Og de 
politisk-religiøse bevægelser i Gaza har tidligere modtaget penge fra Saddam Husseins regime i Irak.

Alle disse kommunikationslinjer og pengestrømme afslører i hvert fald én ting: En betydelig pragmatisme - politisk og religiøst - både i Gaza og i Iran. Det shiitiske Iran er villigt til at alliere sig med det sunnimuslimske Hamas, hvis det kan give Iran en vis indflydelse (ligesom præstestyret i Iran var rede til at modtage amerikanske penge og israelske våben under 80'ernes otte-årskrig ved Golfen). Og modsat: Hamas har heller ingen fine fornemmelser, når det søger hjælp. Bevægelsen modtager formentlig gerne og samtidig hjælp fra det shiitiske Iran og fra det (sunni-) muslimske broderskab i Egypten, mens den aktivt søger økonomisk støtte fra vestlige regeringer, som Hamas ellers politisk, moralsk og på enhver anden måde lægger afstand til.

Af alt dette kan ikke nødvendigvis udledes, at Hamas er skruppelløst eller uden præferencer. Men det kan konstateres, enten at Hamas ikke er dogmatisk og ufravigeligt for Iran og imod Vesten, eller at den palæstinensiske økonomi er så meget $\mathrm{i}$ ruiner, at en hvilken som helst regering i Gaza er nødt til at søge hjælp, hvor som helst den kan få det. Begge dele kan være sandt.

Det har givet Iran en sprække til indflydelse i det palæstinensiske Gaza. Det kunne også give vestlige regeringer en mulighed for indfly- delse, hvis de ville opgive tabuiseringen af Hamas og søge dialog med organisationen. Men Iran og Vesten havde indtil dette forår valgt forskelligt: Iran gjorde brug af sine muligheder hos Hamas. USA og EU-kredsen valgte derimod efter Hamas' valgsejr i 2006 at satse på taberen, Fatah.

Men det var ikke Iran, der hjalp Hamas frem til valgsejren eller den militære sejr over Fatah i maj 2007. Valgsejren kan tilskrives den massive korruption og den dårlige økonomi i de palæstinensiske områder under Fatahs politiske ledelse. Og Hamas' militære fortrængning af Fatah kunne navnlig tilskrives, at Fatahs folk knap ville slås og ikke nød synderlig opbakning.

\section{Nye alliancer}

Hamas har ikke været ene om en betydelig pragmatisme i de aktuelle konflikter:

Fatah har gerne villet modtage penge $o g$ våben fra sin principielle arvefjende, Israel, som det strengt taget mangler at afslutte sin konflikt med.

Israel har på sin side gerne villet bevæbne sin arvefjende, Fatah, uanset at våbnene senere kan blive anvendt i kampen for en selvstændig palæstinensisk stat.

Saudi-Arabien og Egypten har i 2006 ifølge de bedste FN-kilder i dølgsmål opfordret Israel til at gøre en ende på Hizbollah i Sydlibanon, 
uanset at det saudiske og det egyptiske regime officielt fordømte krigen. Hvorfor? Fordi de konservative arabiske regimer selv er livrædde for væbnede religiøse militser i deres egne lande og nødig så Hizbollah vinde hverken en militær sejr eller en heltestatus i den arabiske verden. Israel indstillede alligevel, presset af USA, sine bombardementer, før Hizbollah var smadret, og Hizbollah fik derfor til Egyptens og Saudi-Arabiens fortrydelse en politisk sejr.

Også USA har været villig til at revurdere politiske alliancer. Supermagten var nu i foråret 2007 rede til at bryde med tre et halvt års års ensidig støtte til de gamle shiitiske militser i Irak ved at påbegynde et forsigtigt samarbejde med nogle af de sunnibevægelser, som hidtil havde været på USA's sigtekorn i Irak. Den amerikanske regering havde ikke tidligere været i tvivl om, at disse bevægelser kæmpede for at bringe det tidligere totalitære regime tilbage til magten i Bagdad. Derfor havde USA selv forbudt Baath-partiet og selv opløst Saddam Husseins militær.

Men hvis den amerikanske indsats for at holde sammen på den irakiske stat skulle have en chance, måtte USA opgive et ensidigt samarbejde med shia på bekostning af sunni. I foråret 2007 valgte USA derfor at søge et samarbejde med sunni-militser imod de al-Qaeda-tilknyttede militser i landet.

Det fordrede ikke kun en amerikansk svingtur. De irakiske sunni-mi- litser demonstrerede selv pragmatisme ved efter tre et halvt års væbnet kamp mod fremmede styrker i Irak at hjælpe amerikanske soldater med at angribe al-Qaeda, som opfattes som et fremmedelement.

I alle tilfælde har nationalisme og umiddelbare sikkerhedspolitiske interesser fået forrang for ideologiske og religiøse principper.

\section{Interesser først}

Alt dette bekræfter det gamle vilkår, som også gælder for magthavere i Mellemøsten, at der ikke er nogen permanente venner, kun interesser. Og det er ikke nødvendigvis religiøse markører eller ideologiske facetter, som driver spillet, men netop konkrete, umiddelbare interesser. Regeringerne er opsat på at beskytte sig selv og egne grænser. Om det så kræver samarbejde med unævnelige makkere.

Det hørte sådan set også til konklusionen i den amerikanske tværpolitiske Baker-Hamilton-rapport, som opfordrede Bush-regeringen til at forhandle med alle Iraks nabolande, ikke kun USA's hidtidige venner i Kuwait, Jordan og Saudi-Arabien, men også to slyngelstater i USA's optik: Iran og Syrien. Ikke af sympati for regimerne i Teheran og Damaskus, men i erkendelse af deres potentielle magt og muligheden for at identificere en fælles interesse $i$ at skabe ro i Irak.

Ikke tale om, svarede Bush-rege- 
ringen i første omgang i 2006. I foråret 2007, indvilligede Bush i at lade amerikanske og iranske ambassadører mødes i Bagdad til samtaler om stabilisering af Irak.

Men hvis Irans interesse i mødet var klar, var USA's interesse mere tvivlsom. Iran var slet og ret interesseret $i$ af slippe ud af amerikanske $ø$ konomiske sanktioner; til dét formål kunne Iran også handle om en lukning af Iraks grænser for diverse tilrejsende terrorister. Til gengæld havde præstestyret intet ønske om at gøre indrømmelser i striden om dets omstridte atomprogram.

Iran ville selv berige uran, ikke nøjes med europæisk brændstof til civile reaktorer, og selv bemægtige sig hele denne avancerede teknologi, uanset af dets naboer ikke var og ikke er trygge ved det. USA var nok interesseret $\mathrm{i}$ at få Irans hjælp til at standse opløsningen i Irak, men ikke interesseret $\mathrm{i}$ at droppe eller mindske presset på Iran for at hindre det $i$ at udvikle en iransk atombombe med risiko for et nyt atomvåbenkapløb i Mellemøsten.

Det foreløbige resultat? For begge parter har de langsigtede og modsatrettede interesser været større end de kortsigtede, som kunne friste til dialog.

\section{Syriens rolle}

Vestlige regeringer har herefter kastet deres øjne på Syriens rolle. Umiddelbart skulle regimet i Da- maskus ikke mindst have en interesse i at få Golan-højderne tilbage efter 40 års israelsk besættelse.

Den israelske avis Haaretz kunne her i foråret 2007 med overbevisende kilder dokumentere, at hemmelige forhandlinger mellem israelske og syriske repræsentanter og schweiziske mellemmænd har formuleret en fredsaftale, der kan hjælpe Syrien til at få Golan tilbage, rub og stub, til gengæld for fred i form af åbne grænser og direkte samarbejde med Israel. Men Syrien og Israel har flere mellemværender og interesser end blot Golan. Israel kræver ikke alene åbne forbindelser mellem de to lande, hvilket i sig selv ville være en belastning for det indadvendte regime i Damaskus, som knap har åbne forbindelser til andre arabiske samfund. Israel kræver også, at Syrien vil hindre Iran $i$ at blande sig $i$ Sydlibanon, og at Syrien vil smide Hamas' øverste leder, Khaled Meshal, ud af Damaskus.

Syriens modkrav har også med Libanon at gøre. Assad-regimet i Damaskus vil dels have løfter om, at FN aldrig igangsætter dét tribunal, som skal retsforfølge de ansvarlige for mordet på Libanons tidligere regeringschef, Rafiq Hariri, i Beirut i februar 2005. Godt nok forsværger det syriske regime at have noget som helst med dette mord at gøre. Men regimet vil for alt i verden undgå, at tribunalet begynder at snuse $\mathrm{i}$ syriske affærer. Og libanesiske henvendelser til FN og USA antyder, at 
Syriens interesse for libanesiske sager rækker endnu længere. "Nu sælger I vel ikke os”, spørger libaneserne i både USA og FN. De er på vagt over for, at USA eller Israel vil give Syrien overhøjhed i Libanon.

Set fra et moralsk synspunkt ville det sikkert være forkasteligt. Libanon har vel samme ret til suverænitet som andre stater. Men set fra en kynisk og såre pragmatisk vinkel kunne det give mening at lade Syrien få råderet over Libanon. Det syriske regime har vist sig effektivt til at håndhæve våbenstilstanden i Golan; det er ikke bange for at anvende magt; det er godt bekendt med Libanon, og det havde reelt en solid kontrol med Libanon i 15 år fra 1990-2005, ja lige indtil Hariri-mordet, som til overraskelse for Damaskus fik flertallet af libaneserne til at kræve de syriske soldater ud af landet. Alligevel: Hvis nogen stat kan gøre sig håb om at kontrollere Libanon, vil det formentlig være Syrien.

Umiddelbart er det stabilitet, alle de statslige aktører i Mellemøsten savner. Det er - om ikke moralsk, så konkret - rigtigt, at Irak ikke var truet af opløsning, mens Saddam Hussein havde magten. Libanons enorme konfliktpotentiale var holdt bedre i skak, mens Syrien kontrollerede dette land. Og Gaza var også mere stille, da Israels besættelsesmagt var på sit mest effektive.

Ikke desto mindre vil hverken lokale magthavere eller det såkaldte 'internationale samfund' ønske sig
Saddam Hussein tilbage, heller ikke umiddelbart ønske sig en syrisk genbesættelse af Libanon eller ønske sig, at Israel genoptager besættelsen af Gaza.

Det fremadrettede behov er på langt sigt et andet: at Irak, Libanon og 'Palæstina' slipper af med udenlandsk besættelse. At de tre samfund sikres en stabil og legitim statsmagt, og at der investeres i opbygning, ikke nedbrydning.

Både for de mellemøstlige regeringer og for omverdenen har det været rystende at iagttage, at de hidtidige undertrykkende magtforhold i dén grad er blevet erstattet af opløsning.

Derfor kan det alligevel være for sent at retablere totalitære forhold og besættelser.

\section{Religiøs vækkelse?}

På overfladen er regeringer i de konservative og verdslige arabiske stater ligesom Israel, USA og Europa bange for den politisk-religiøse vækkelse og organisering, som umiddelbart synes bag den voldsomme udvikling i Irak, Libanon og Gaza.

Iran har ikke skabt vækkelsen; dén skyldes primært moskeernes og de sociale og religiøse netværks stærke position. Andre politiske netværk har gerne været under kontrol. Moskeerne har haft bedre muligheder for at samle folkemasser og sprede budskaber. 
Og det omsiggribende budskab er reelt politisk, ikke religiøst, såvel i de tre konfliktlande som i andre arabiske stater, hvor regeringer frygter at blive indhentet af krav om forandring. Det gælder ikke mindst Egypten, hvor Hosni Mubaraks totalitære regime er presset af Det Muslimske Broderskab; det gælder også Bahrain hvor den sunnnimuslimske hersker er presset af det reformkrævende shiitiske befolkningsflertal, det gælder i Saudi-Arabien hvor kongefamilien udfordres af både militante jihadister og af politiske reformkrav - og det gælder ret beset også i Syrien, hvor Bashar Assads regime viser tegn på uro for det sunnimuslimske broderskabs evne til at udfordre diktaturet.

\section{Reformkrav}

De verdslige regimer i Arabien har ikke været sene til at bruge konflikterne i Irak, Libanon og Gaza som argument imod krav om politiske reformer.

De vestlige regeringer er derimod fanget på ét ben. Både USA og EUkredsen har i fire-fem år opfattet terrornetværk som ét af resultaterne af cocktailen svage stater, totalitære regimer, manglende $\varnothing$ konomisk vækst og jævn intolerance. De har også i dét lys fået gode grunde til at frygte opløsningen i Irak, Libanon og Gaza. Men selv regeringerne i Saudi-Arabien og Egypten har fået læst denne lektie fra amerikansk hold. Og såvel i USA som i EU-kredsen er det stadig en analyse, som holder. Det gør ønsket om politiske reformer i vennelandene Egypten, Saudi-Arabien og Bahrain derfor også - for slet ikke at tale om krav til 'slyngelstaten' Syrien.

På kort sigt kan frygten for Irak, Libanon og Gaza dog tale for ikke at skubbe til stabiliteten i de stater, der stadig nyder godt af magtfulde regeringer. På den anden side siger de dominerende vestlige analyser også, at den herskende stabilitet er at spørgsmål om tid, hvis de nuværende regeringer ikke giver reformer økonomisk og politisk - en chance.

Politisk-religiøse netværk som Hizbollah i Libanon, Hamas i Gaza og Sadr's bevægelse i Irak har ikke holdt sig tilbage fra at udfordre enhver stabilitet, der bygger på undertrykkelse. Det samme gælder Det Muslimske Broderskab i Egypten, Jordan og Syrien og tilsvarende netværk i Bahrain og Saudi-Arabien.

Det er ikke alle netværk, der pr. definition nødvendigvis er antidemokratiske. Men hidtil har Vesten i modsætning til Iran ikke for alvor søgt indflydelse i de politisk-religiøse bevægelser.

I dag ser vi opløsningen i foreløbig tre stater. Resultatet kender vi ikke, heller ikke resultatet af at udskyde reformer i de andre stater.

Anders Jerichow, kronikredaktør, Politiken og redaktør, Udenrigs. 